Kondo, T., K. Terada, E. Hayashi, N. Kuramoto, M. OKAMURA and H. KAWASAKI (2000): RAPD markers linked to a gene for resistance to pine needle gall midge in Japanese black pine (Pinus thunbergii). Theor Appl Genet 100: 391-395.

KosambI, D. D. (1994): The estimation of map distances from recombination values. Ann Eugen 12: 172-175.

Kubo, H., A. J. M. Peeters, M. G. M. Aarts, A. Pereira and M. KoORNNEEF (1999): ANTHOCYANINLESS2, a homeobox gene affecting anthocyanin distribution and root development in Arabidopsis. Plant Cell 11: 1217-1226.

LAUX, T. and G. JÜRGENS (1997): Embryogenesis: a new start in life. Plant Cell 9: 989-1000.

MATHER, K. (1938): The measurement of linkage in heredity (Methuen's monographs on biological subjects). Methuen, London.

Mayer, U., R. A. Torres Ruiz, T. Berleth, S. Misera and G. JÜRGENS (1991): Mutations affecting body organization in the Arabidopsis embryo. Nature 353: 402-407.

Michelmore, R. W., I. Paran and R. V. Kesseli (1991): Identification of markers linked to disease resistance genes by bulked segregant analysis: a rapid method to detect markers in specific genomic regions by using segregating populations. Proc Natl Acad Sci USA 88: 9828-9832.

NATESH, S. and M. A. RAU (1984): The embryo. In: embryology of angiosperms. (ed. B. M. JoHRI), Springer-Verlag.

SAX, K. (1923): The association of size differences with seed-coat pattern and pigmentation in Phaseolus vulgaris. Genetics 8: 552-560.

Scheres, B., H. Wolkenfelt, V. Willemsen, M. Terlouw, E. LaWson, C. Dean and P. Weisbeek (1994): Embryonic origin of the Arabidopsis primary root and root meristem initials. Development 120: 2475-2487.

Stirling, B., G. Newcombe, J. VRebalov, I. Bosdet and H. D. BRADSHAW (2001) Suppressed recombination around the MXC3 locus, a major gene for resistance to poplar leaf rust. Theor Appl Genet 103: 1129-1137.

Tixier, M. H., R. M. Sourdille, P. Leroy and M. Bernard (1997): Detection of wheat microsatellites using a non radioactive silver-nitrate staining method. J Genet Breed 51: 175-177.
Vernoux, T., R. C. Wilson, K. A. Seeley, J. P. Reichheldt, S. Muroy, S. Brown, S. C. Maughan, C. S. Cobbett, M. V. Montagu, D. Inzé, M. J. May and Z. R. Sung (2000): The ROOT MERISTEMLESS1/ CADMIUM SENSITIVE2 gene defines a glutathionedependent pathway involved in initiation and maintenance of cell division during postembryonic root development. Plant Cell 12: 97-110.

Villar, M., F. Lefìvre, H. D. BradshaW and E. T. Ducros (1996): Molecular genetics of rust resistance in poplars (Melampsora larici-populina Kleb/Populus sp.) by bulked segregant analysis in a $2 \times 2$ factorial mating design. Genetics 143: 531-536.

Vos, P., R. Hogers, M. Bleeker, M. Reijans, T. van DE Lee, M. Hornes, A. Frijters, J. Pot, J. Peleman, M. KUIPER and M. ZABEAU (1995): AFLP: a new technique for DNA fingerprinting. Nucleic Acids Res 23: 4407-4414.

Wilcox, P. L., H. V. Amerson, E. G. Kuhlman, B. H. LiU, D. M. O. Malley and R. R. SederofF (1996) Detection of a major gene for resistance to fusiform rust disease in loblolly pine by genomic mapping. Proc Natl Acad Sci 93: 3859-3864.

Willemsen, V., H. Wolkenfelt, G. VRieze, P. Weisbeek and B. Scheres (1998): The HOBBIT gene is required for formation of the root meristem in the Arabidopsis embryo. Development 125: 521-531.

Zhang, D., Z. Zhang, W. Song and K. Yang (2003). Optimizing segregation population selection for genetic linkage maps in Populus tomentosa Carr.. Journal of Beijing Forestry University 25: 22-25.

ZHANG, D., Z. ZHANG, K. YANG and B. LI (2004): Genetic mapping in (Populus tomentosa $\times$ P. bolleana) and $P$. tomentosa Carr. using AFLP markers. Theor Appl Genet 108: 657-662.

Zhang, Z. Y., Z. H. Huang, D. F. Zhang, F. W. Su, Y. H. ZHANG and F. X. Dong (1992): An investigation on flowering and bearing of clones in the arboretum of Populus tomentosa Carr.. Journal of Beijing Forestry University 14: 41-51.

Zhu, Z. T. and Z. Y. ZhANG (1997): The status and advances of genetic improvement of Populus tomentosa Carr.. Journal of Beijing Forestry University (English Edition) 6: 1-7.

\title{
Growth Performance and Variability in Different Clones of Gmelina arborea (RoxB.)
}

\author{
By A. KumAR*) \\ Division of Genetics \& Tree Propagation, Forest Research Institute, Dehradun 248 195, Uttaranchal, India
}

(Received 20 th December 2005)

\begin{abstract}
A clonal trial of Gmelina arborea consisting of seventy clones selected from ten geographical locations in four

\footnotetext{
*) Corresponding author: AsHoK KumAR. Telephone: +91-135 2755473, Fax: +91-135-2756865. Email: ak_meena@yahoo.com \& ashokumar@icfre.org
}

states of northeast India was evaluated for height, diameter at ground level (DGL) and diameter at breast height (DBH) at the Experimental Station, Rain Forest Research Institute, Jorhat, Assam, India. The performance of all the traits at the age of 24 months showed significant variations between the clones. Broad sense heritability for height, DGL and DBH was $0.31,0.44$ 
and 0.37 with a genetic gain of $18.1,24.6$ and $30.1 \%$, respectively. Diameter at breast height $(\mathrm{DBH})$ was determined to be an important trait with maximum genotypic and phenotypic coefficients of variation of 18.6 and $30.4 \%$, respectively.

Clones selected from the geographical location of Lanka (Assam) were better performers over other locations. Clone 106 attained the greatest height $(517 \mathrm{~cm})$ and DGL (119 mm), whereas Clone 108 performed poorly for all the traits studied. Clone 106 maintained its superiority from an early age of 12 months. Clones 009, 017 and 079 showed an increasing trend for height, and markedly changed rankings from $13^{\text {th }}, 15^{\text {th }}$ and $20^{\text {th }}$ positions at the age of 12 months to $2^{\text {nd }}, 4^{\text {th }}$ and $15^{\text {th }}$ positions at 24 months of age. The interim assessment of different clones indicated large genetic improvement possibilities in G. arborea.

Key words: Gmelina arborea, clones, heritability, genetic advance, genetic gain.

\section{Introduction}

The demand for wood and wood based products has continuously been on the increase, and is likely to further increase with continuous growing rate of literacy, liberalization of economic policies and advancement of utilization technology. The requirement of various woods in India by 2010 has been projected to 344 million $\mathrm{m}^{3}$ of fuel wood and charcoal, 37 million $\mathrm{m}^{3}$ industrial wood, 33 million $\mathrm{m}^{3}$ sawn timber, 5.7 million $\mathrm{m}^{3}$ pulp and paper wood and 1.3 million $\mathrm{m}^{3}$ wood based panels (ANON, 1993). However, the problem is extremely serious due to low productivity of Indian forests of 0.5 to $0.7 \mathrm{~m}^{3} \mathrm{ha}^{-1} \mathrm{yr}^{-1}$ against world average of $2.5 \mathrm{~m}^{3} \mathrm{ha}^{-1} \mathrm{yr}^{-1}$ (LAL, 2000).

Significant improvement in yield has been achieved in many forest species through application of selection and breeding coupled with clonal forestry. Capture of nonadditive variation is possible only by adopting clonal approach. The approach is also particularly attractive in capturing gains for characters that have low heritabilities (ZoBEL, 1981) and in the exploitation of hybrids. The productivity of Populus and Eucalyptus plantations has been appreciably increased through the clonal approach. Clonal multiplication of trees with desired traits could become commercially acceptable in Gmelina arborea as well.

Gmelina arborea (RoxB.) belongs to the family Verbenaceae, and is distributed eastwards from Pakistan, throughout India, Bangladesh and Myanmar to parts of Sri Lanka, Thailand, Laos, Cambodia, Vietnam, China and Yunnan. In India, it is found in the eastern subHimalayan tract, the Indo-gangetic plains, the Aravalai Hills, central India, the western peninsula and the western Himalayas (Fig. 1). It contributes substantially in timber, industrial wood and fodder production and is grown extensively both on government and private lands of northeastern India. Application of clonal forestry in Gmelina arborea could immensely increase the productivity and contribute substantially in narrowing the gap between demand and supply. Clonal forestry however is only successful with genetically superior clones and therefore present paper is a start towards testing and selection of elite clones.

\section{Material and Methods}

A total of seventy clones (Figure 2 and Table 1) were randomly selected from 119 clones established in a clone/gene bank and multiplied vegetatively through chip budding. The clonal trial was established at the Experimental Station, RFRI, Nahorani about $30 \mathrm{~km}$ from Jorhat during 2000 in a completely randomised block design with three replication and five ramets of each clone planted in a row. Measurements were taken every 6 months for height, diameter at ground level (DGL) and diameter at breast height (DBH). Following analysis was carried out using statistical package for social studies (SPSS).

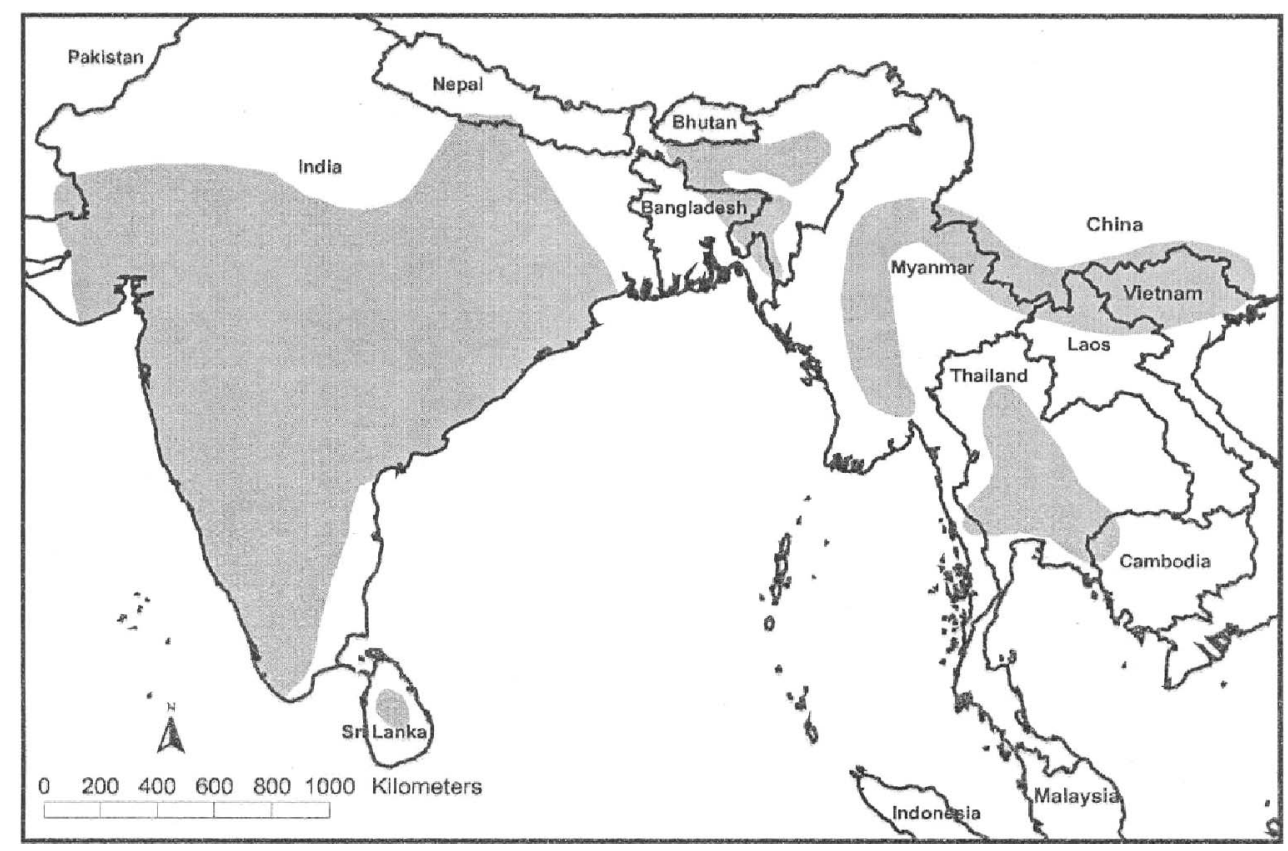

Figure 1. - Map for geographical distribution of Gmelina arborea. 


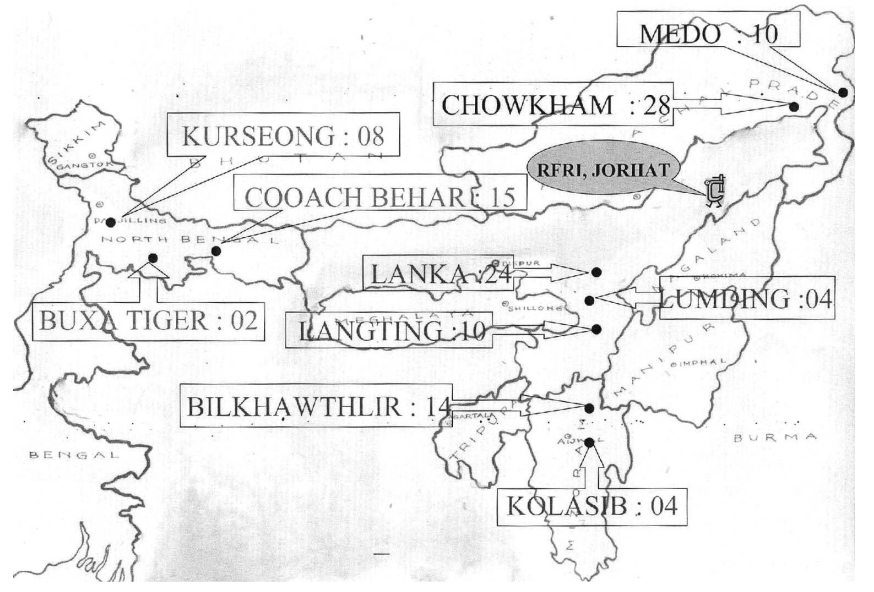

Figure 2. - Location map for the plus trees of Gmelina arborea.

\section{Analysis of variance}

The observation taken in the month of July 2002 was analysed for analysis of variance (ANOVA) as per SuKHATME and AMBLE (1989).

\section{Variance}

The genotypic and phenotypic components of variance were calculated from the ANOVA as described by BuRTON (1952).

- Genotypic variance

$\left.\left.\left(\sigma^{2} \mathrm{~g}\right)=\left(\sigma^{2} \mathrm{e}+R \sigma^{2} \mathrm{c}\right)-\sigma^{2} \mathrm{e}\right)\right) / \mathrm{r}$ (Where $\mathrm{r}$ represents number of replications)

- Phenotypic variance $\left(\sigma^{2} p\right)=\sigma^{2} g+\sigma^{2} e$

- Genotypic Coefficient of variance $\mathrm{GCV}=\left(\sqrt{ } \sigma^{2} \mathrm{~g} /\right.$ mean $) \times 100$

- Phenotypic coefficient of variance $\mathrm{PCV}=\left(\sqrt{ } \sigma^{2} \mathrm{p} / \mathrm{mean}\right) \times 100$.

\section{Heritability}

Broad sense heritability was calculated as per LUSH (1949).

$$
\mathrm{h}^{2}=\sigma^{2} \mathrm{~g} / \sigma^{2} \mathrm{p} \times 100 .
$$

\section{Genetic Advance}

The genetic advance was calculated as described by JoHNSON et al. (1955).

$(\mathrm{Gs})=\mathrm{K} \cdot \mathrm{h}^{2} \cdot \sqrt{ } \boldsymbol{\sigma}^{2} \mathrm{p}($ Where, $\mathrm{K}=2.66)$.

\section{Genetic gain}

The expected genetic gain, in per cent of mean, was calculated following BURTON and DEVANE (1953).

Genetic gain $=(\mathrm{Gs} /$ mean $) \times 100$.

\section{Results and Discussion}

The genetic parameters are useful tools in predicting the amount of gain to be expected from clonal material. The variation between clones is commonly used as an estimate of total genetic variation and to calculate the degree of genetic control for a particular trait (FOSTER and SHAW, 1988). Though the selection of superior trees was carried out using index method of selection with intensive selection criteria (KUMAR et al., 2003), genetic superiority per se had to be demonstrated. Using analytical tools, variance (both genotypic and phenotypic), broad sense heritability, genetic advance and genetic gain for height, DGL and DBH were calculated and are presented in Tables 2 and 3. Although all 70 clones were planted under uniform conditions, significant differences were found in growth behaviour for all the traits in various clones. Height ranged from 233 (clone 108) to $518 \mathrm{~cm}$ (clone 106) with a variation of $122 \%$. DGL ranged from 57 (clone 108) to $119 \mathrm{~mm}$ (clone 106) and $\mathrm{DBH}$ ranged from 24 (clone 108) to $72 \mathrm{~mm}$ (clone 17) to

Table 1. - Details of Gmelina arborea clones and their source selected for clonal trial.

\begin{tabular}{|l|l|c|}
\hline Geographical location & State & No. of clones \\
\hline Medo & Arunachal Pradesh & 8 \\
Chowkham & Arunachal Pradesh & 1 \\
Lanka & Assam & 17 \\
Langting & Assam & 8 \\
Lumding & Assam & 2 \\
Bilkhawthlir & Mizoram & 7 \\
Kolasib & Mizoram & 3 \\
Cooch Behar & West Bengal & 15 \\
Kurseong & West Bengal & 8 \\
Buxa Tiger Reserve & West Bengal & 1 \\
& & $\mathbf{7 0}$ \\
\hline
\end{tabular}

Table 2. - Analysis of variance for different traits.

\begin{tabular}{|l|c|c|c|c|}
\hline \multirow{2}{*}{$\begin{array}{l}\text { Source of } \\
\text { variation }\end{array}$} & Degrees of & \multicolumn{3}{|c|}{ Mean sum of squares } \\
\cline { 2 - 5 } freedom & 69 & $10555.47^{* *}$ & $633.59^{* *}$ & DBH \\
\hline Clones & 2 & 58404.64 & 3598.29 & $102.62^{* *}$ \\
Replications & 138 & 4469.52 & 187.83 & 134.04 \\
Residual & \multicolumn{4}{|l|}{ Significant at 1 per cent level of significance } \\
\hline
\end{tabular}


Table 3. - Different genetic parameters estimated for 70 clones of Gmelina arborea.

\begin{tabular}{|l|c|c|c|}
\hline Genetic parameter & Height & DGL & DBH \\
\hline Genetic variance $\left(\boldsymbol{\sigma}^{\mathbf{2}} \mathbf{g}\right)$ & 2028.7 & 148.6 & 79.9 \\
Phenotypic variance $\left(\boldsymbol{\sigma}^{\mathbf{2}} \mathbf{p}\right)$ & 6498.2 & 336.4 & 213.9 \\
Broad sense heritability $\left.\mathbf{( h}^{\mathbf{2}}\right)$ & 0.31 & 0.44 & 0.37 \\
Genetic advance $(\mathbf{G s})$ & 66.9 & 21.5 & 14.5 \\
Genetic gain $(\boldsymbol{\%})$ & 18.1 & 24.6 & 30.1 \\
Genotypic Coefficient of variance (GCV) & 12.2 & 13.9 & 18.6 \\
Phenotypic coefficient of variance (PCV) & 21.9 & 20.9 & 30.4 \\
\hline
\end{tabular}

with a variation of 109 and $200 \%$ for both the characters, respectively. Amongst 70 clones, clone 106 was found to be an exceptional clone by achieving maximum values for both height and DGL.

The data presented in the analysis of variance table (Table 2) showed that values for all the traits were highly significant. The genotypic and phenotypic coefficient of variation for all the characters provided evidence for the existence of adequate genotypic variations. The data presented in Table 3 showed that $\mathrm{DBH}$ was the most important trait with maximum genotypic and phenotypic coefficient of variation of 18.55 and $30.37 \%$, respectively. The results showed that considerable inter clonal variation exists for further genetic improvement.

The heritability expresses the degree to which a character is influenced by genes as compared to the environment. Estimation of broad sense heritabilities for various characters (Table 3) showed moderate heritability for height (0.31), DGL (0.44) and DBH (0.37), and are in conformity with the results of NELSON and TAUER (1987) in poplars. They reported moderate to high broad sense heritabilities for juvenile traits such as height, diameter, growth and leaf size. Nonetheless, there is a need to estimate narrow-sense heritabilities for individual growth components so that additive genetic variance associated with individual growth components can be calculated, because these estimates facilitate selection on those traits from which a positive genetic response can be expected at reasonable selection intensity. In the present study greatest genetic advance was observed for height (66.94) followed by DGL (24.60) and DBH (14.52). However, maximum genetic gain $(30.2 \%)$ was reported for $\mathrm{DBH}$ and was moderate for DGL $(24.6 \%)$ and height $(18.2 \%)$. Genetic gain for all the traits has been positive, particularly for the most important trait of $\mathrm{DBH}$.

The described heritabilities, genetic advance and genetic gain were estimated at relatively early stage of 24 months after planting. The growth rate generally enters the log phase in third or fourth year of age, thus heritability estimates carried out at that age would be more accurate. The present results, however, can serve as an indicator to be compared with the results to be obtained at later stages and also to establish the corre-

Table 4. - Change in the ranking for height in different clones of Gmelina arborea.

\begin{tabular}{|c|c|c|c|c|}
\hline \multirow[t]{2}{*}{ Ranks } & \multirow[t]{2}{*}{ Clone No. } & \multicolumn{3}{|c|}{ AGE OF PLANTS } \\
\hline & & 12 Months & 18 Months & 24 Months \\
\hline $\mathbf{1}$ & 106 & $178(106)=$ & $306(106)=$ & $=517(106)$ \\
\hline 2 & 101 & $167(101)$ & $278(009)$ & $-491(009)$ \\
\hline 3 & 37 & $164(037)$ & 277 (099) & $491(086)$ \\
\hline 4 & 3 & $162(003)$ & $-268(101) \backslash$ & $485(017)$ \\
\hline 5 & 39 & $161(039)$ & $263(017)=$ & 475 (099) \\
\hline 6 & 8 & $158(008)$ & $262(039)$ & $461(008)$ \\
\hline 7 & 16 & $157(016)$ & $259(003)$ & $449(037)$ \\
\hline 8 & 38 & $156(038)$ & $254(038)$ & $448(039)$ \\
\hline 9 & 7 & $155(007)$ & $254(016)$ & $440(003)$ \\
\hline $\mathbf{1 0}$ & 11 & $153(011)$ & $252(008)$ & 435 (038) \\
\hline 11 & 4 & $152(004)$ & $242(037)$ & $431(016)$ \\
\hline 12 & 99 & $152(099)$ & - $241(011)$ & ' $430(101)$ \\
\hline 13 & 9 & $150(009)$ & - 239 (007) & $420(004)$ \\
\hline 14 & 86 & $148(086)$ & $239(102)$ & - 417 (011) \\
\hline 15 & 17 & $147(017) / /$ & 238 (112) & $410(079)$ \\
\hline 16 & 27 & $143(027)-$ & $235(086)$ & 403 (102) \\
\hline 17 & 116 & $140(116)$ & $229(027)$ & $400(116)$ \\
\hline 18 & 102 & $132(102)$ & $227(079)$ & •398(007) \\
\hline 19 & 112 & $132(112)$ & $225(004)$ & 395 (112) \\
\hline 20 & 79 & $120(079)$ & $218(116)$ & $394(027)$ \\
\hline \multicolumn{2}{|c|}{ Average } & 151.4 & 250.3 & 439.5 \\
\hline \multicolumn{2}{|c|}{ S.D. } & 13.4 & 21.5 & 36.9 \\
\hline
\end{tabular}


lations. Assessment at 3 to 4 years would determine whether genetic analysis at early stage is reliable.

If found reliable, genetic assessment for other populations could also be carried out with suitable correlation factors or the extent of the relationship can be determined. In the present study, clones $8,9,16,17,37,39$ and 106 were the best performers for all traits. Their superiority, however, needs to be tested over period of time to make suitable recommendations. On the basis of mean height at the age of 24 months, thirty-two of seventy clones were taller than the mean height $(369 \mathrm{~cm})$. A total of $38 \%$ of the clones from geographical locations in Lanka were found to be above average mean height followed by Cooch Behar (22\%) and Medo (13\%). This reflects superiority of selections from Lanka over other geographical locations.

The top twenty clones in terms of mean height were assessed for their ranking at the age of 12 (May 2001), 18 (December 2001) and 24 (August 2002) months (Table 4). Clone 106 maintained $1^{\text {st }}$ rank over the period. Clones 9, 17 and 79 showed a upward trend whereas clones $3,7,11,16,27,39$ and 101 showed a decreasing trend. Though average increment for these 20 selected clones from May 2001 to August 2002 was $190 \%$, clones 79,17 and 9 showed an increment of 242, 230 and $227 \%$, respectively. The results are clear indications that testing of clones needs to be carried out for longer durations so that elite genotypes are identified and deployed thorough plantations programmes. It is also necessary to examine the trend of all the clones over the years and to group different clones for various end uses. The rapid growing clones may well be used to establish biomass plantations for paper industry whereas slower growing clones may be recommended for timber and furniture industry. However, individual clones needs to be analysed for different wood properties before recommending their deployment through plantations programmes. Nonetheless, described results indicate clonal behaviour only for height at one single location and needs to be tested for real superiority per se at different locations.

\section{Acknowledgement}

Authors are thankful to the Director, Rain Forest Research Institute, Jorhat for his continuous encouragement and support. Thanks are also due to World BankForestry Research Education \& Extension Project for financial support.

\section{References}

ANON (1991): Forestry statistics today for tomorrow. Wood and wood products 1961-1989: 2010. Food and Agriculture Organization of the United Nations, Rome.

BurTon, G. W. (1952): Quantitative inheritance in grass. In: $6^{\text {th }}$ International Grassland Congress, Part I: 277-283.

Burton, G. W. and E. H. Devane (1953): Estimating heritability in tall fecue (Festuca arundinaceae) from replicated clonal material. Agron. J. 45: 478-481.

Foster, G. S. and D. V. SHAW (1988): Using clonal replicates to explore genetic variation in a perennial plant species. Theor. Appl. Genet. 76: 788-794.

Johnson, H. K., H. F. RABInson and R. E. Comstock (1955): Estimates of genetic and environmental variability in soybeans. Agron. J. 47: 314-318.

Kumar, A., P. H. ChaWhaAn and A. K. Matharoo (2003): Improvement through selection of plus trees in Gmelina arborea. Journal of Tropical Forest Science 15 (3): 441-449.

LAL, P. (2000): National forest policy and raw materials: Supply by wood industries in India. Indian Forester 126 (4): 351-366

LUSH, I. L. (1949): Heritability of quantitative characters in farm animals. Heriditas. Suppl: 356-387.

Nelson, C. D. and C. G. TAuer (1987): Genetic variation in juvenile characteristics of Populus deltoides from Southern Great Plains. Silvae Genet. 36: 216-221.

Sukhatme, P. V. and V. N. AmBle (1989): Statistical Methods for Agricultural Workers. Publication and Information Division, ICAR, New Delhi. P 359.

ZoBEL, B. J. (1981): Vegetative propagation in forest management operations. In: Proc., $16^{\text {th }}$ South For. Tree Improv. Meet., Blacksburg, Virginia. pp. 149-159.

\title{
A Study of Population Variation and Inheritance in Sitka Spruce
}

\section{IV: Correlated response in the progeny population based on selection in the parental population}

\author{
By S. J. LeE ${ }^{\left.1)^{*}\right)}$, J. Woolliams ${ }^{2)}$, C. J. A. SAmuel ${ }^{1)}$ and D. C. MAlColm ${ }^{3)}$
}

(Received 22 $2^{\text {nd }}$ December 2005)

\footnotetext{
1) Forestry Research, Northern Research Station, Roslin, Midlothian, EH25 9SY, Scotland.

2) Roslin Institute, Roslin, Midlothian, EH25 9PS, Scotland.

$\left.{ }^{3}\right)$ Edinburgh University, Institute of Ecology and Resource Management, The King's Buildings, Edinburgh, EH9 3JU, Scotland.

*) Communicating author: Steve J. LeE, Tel: +44 (0) 1314456926 , Fax: +44(0) 131445 5124. E-Mail: steve.lee@forestry.gsi.gov.uk
}

\section{Summary}

This study investigated the potential benefits to a tree breeding programme of selection based on height in the original ortet population, and on diameter and wood density of grafted-ramets representing the same ortets growing in a clone bank. The trees studied were a large, randomly selected same-aged population of Sitka spruce 